\title{
Challenges and implications of incorporating multi-cohort management in northeastern Ontario, Canada: A case study
}

\author{
by David A. Etheridge ${ }^{1, *}$ and Gordon J. Kayahara ${ }^{1}$
}

\begin{abstract}
In northeastern Ontario, the natural fire cycle is long, resulting in large areas of forest in an uneven-aged condition. Under Ontario forest legislation requiring emulation of natural disturbance regimes, extended rotations and multi-cohort management present options that may meet landscape targets. We used a forest management wood supply model to compare scenarios of current even-aged management, extended rotations, and multi-cohort management (adds partial harvesting). Because science-based information to incorporate late successional forest stages into wood supply modeling is lacking in boreal Ontario, we adjusted the current even-aged inputs to account for mid- and late-seral conditions. Based primarily on expert opinion, adjustments were made to the Forest Resources Inventory age, yield curves, and succession rules; and partial harvesting was added. For modeling, we specified three broad succession groupings (even-aged, two- to three-aged, and all-aged) and established targets of $50 \%, 25 \%$ and $25 \%$ of the landscape area, respectively. The current even-aged scenario met even-aged targets but not multi-aged targets. Extended rotations and multi-cohort management scenarios met all the succession grouping targets over the long term. Wood supply was highest for the even-aged scenario, slightly lower for multi-cohort management scenario, and much lower for the extended rotations scenario. Road usage and relative cost was highest for the extendedrotations scenario and lowest for the even-aged scenario. Multi-cohort management may represent a compromise between maximizing harvest levels using even-aged management and retaining mid- and late-succession habitat structures.
\end{abstract}

Keywords: emulation of natural disturbance, sustainable forest management, multi-cohort, variable rotations, extended rotations, wood supply

\section{RÉSUMÉ}

Dans le nord-est de l'Ontario, les longs cycles naturels de feux font que de vastes zones de forêt deviennent inéquiennes. Comme la législation forestière de l'Ontario oblige à imiter les régimes de perturbations naturelles, il est envisageable datteindre ces objectifs au niveau du paysage par l'allongement des rotations et l'utilisation de l'aménagement multi-cohortes. Nous avons utilisé un modèle d’approvisionnement en forêt aménagée pour comparer scénario d’aménagement équienne avec ceux comportant un allongement des rotations et un aménagement multi-cohortes (incluant la coupe partielle). Puisque les informations scientifiques pour intégrer les stades de succession écologique tardifs dans la modélisation de lapprovisionnement faisaient défaut pour la région boréale de l'Ontario, nous avons ajusté les paramètres du modèle équienne pour tenir compte des conditions de succession moyenne et tardive. En nous inspirant surtout de lopinion des experts, nous avons ajusté lâge, les courbes de rendement et les règles de successions provenant de linventaire forestier provincial; nous avons ajouté la coupe partielle. Pour effectuer la modélisation, nous avons spécifié trois grands groupes de succession (équienne, deux à trois classes dâge, et tous âges) en plus détablir pour chacun les cibles de $50 \%, 25 \%$ et $25 \%$ respectivement de la superficie du paysage. Le scénario équienne actuel a permis d’atteindre les objectifs équiennes, mais non pas ceux dâges multiples. Lallongement des rotations et les scénarios daménagement gestion multi-cohortes ont permis datteindre à long terme tous les objectifs de regroupement de la succession. Lapprovisionnement en bois était la plus élevé avec le scénario équienne, légèrement inférieur pour le scénario d’aménagement multi-cohortes, et beaucoup plus faible pour le scénario de rotations prolongées. Lutilisation et le coût relatif des routes étaient les plus élevés avec le scénario impliquant lallongement des rotations et minimum avec le scénario équienne. Laménagement multi-cohortes pourrait offrir une avenue de compromis entre la maximisation de la récolte avec laménagement équienne et la rétention des structures d'habitat de mi- et de fin de succession.

Mots-clés : imitation des perturbations naturelles, aménagement durable des forêts, multi-cohorte, rotations variables, rotations allongées, approvisionnement en bois

\footnotetext{
${ }^{1}$ Ontario Ministry of Natural Resources, Science and Information Resources Division, Science and Information Branch, Northeast Science and Information Section, 5520 Hwy 101 East, P.O. Bag 3020, South Porcupine, Ontario P0N 1 H0.

${ }^{\star}$ Corresponding author. E-mail: dave.etheridge@ontario.ca
} 


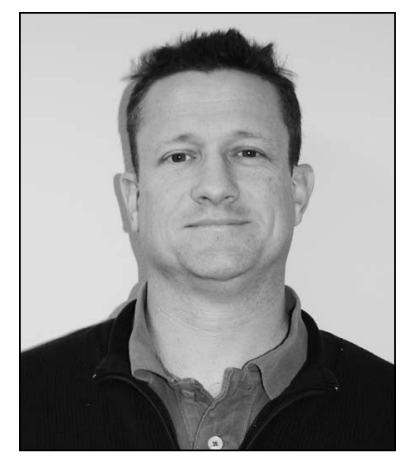

David A. Etheridge

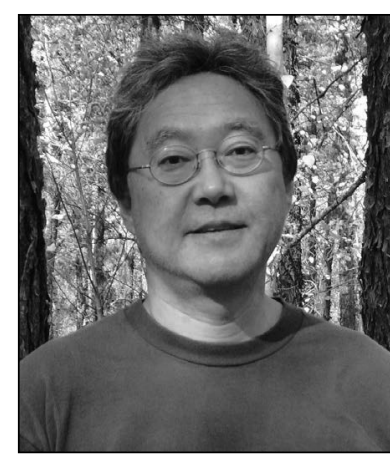

Gordon J. Kayahara

\section{Introduction}

A forest management approach that targets landscape and stand characteristics expected from natural disturbance regimes represents a coarse-filter, ecological forest management approach (The Nature Conservancy 1982) that may achieve a balance between maintaining biodiversity and ecosystem function, and serving human commodity needs (Franklin 1993, Galindo-Leal and Bunnell 1995, Bergeron et al. 1999, Seymour and Hunter 1999). Under this principle, forest management practices aim to operate through the emulation of natural disturbance patterns. The province of Ontario has recognized the importance of basing sustainable forest management on the emulation of "natural disturbances and landscape patterns" through the Crown Forest Sustainability Act (1994).

In northeastern Ontario, relatively long fire cycles associated with more humid boreal climates and the prevalence of wet lowland sites result in the presence of extensive areas of uneven-aged mixedwood, spruce-fir, and black spruce stands in mid- and late-seral stages of succession (Bergeron and Archambault 1993; Bergeron et al. 2001, 2004; Lefort et al. 2003; Grenier et al. 2005). By using the average age of the unharvested portion of a forest as a surrogate for an average long-term fire cycle, the fire cycles associated with northeastern Ontario are much longer than the short fire cycles ( $<100$ years) associated with drier boreal climates and sites (Bergeron et al. 2001, Lefort et al. 2002, Lefort 2003, Cyr et al. 2005). For example, the average age of the unharvested portion of the claybelt was estimated to be 172 years (Bergeron et al. 2001), and even south of the claybelt dominated by poplar, mixedwood, and pine forests, the average age of the unharvested portion of the forest was estimated to be 130 years (Bergeron et al. 2004, Grenier et al. 2005).

If emulation of the natural disturbance pattern is a management objective and we accept that long fire cycles represent the natural forest condition that maintains large portions of the landscape in mid- and late-seral stages in northeastern Ontario, forest managers need to consider alternatives to the primary use of traditional short-rotation, even-aged silviculture (Bergeron 2004). Two possible alternatives are the adoption of variable rotations (Harris 1984, Curtis 1997, Burton et al. 1999, Seymour and Hunter 1999) and/or the multi-cohort approach proposed by Bergeron and Harvey (1997), Bergeron et al. $(1999,2002)$ and Harvey et al. (2002). Under the former strategy, one scenario is to vary rotations within and between species with extended rotations on sites associated with longer fire cycles (site-based extended rotation). Under this scenario, clearcutting is still the primary method of harvesting; thus operationally, this system essentially relies on using current harvesting practices. The latter (multi-cohort) approach represents a framework to incorporate uneven-aged silviculture systems in order to manage for stand structural attributes associated with various seral stages. As envisioned by Harvey et al. (2002), in this approach a variety of silviculture systems are used, including clearcutting for early-seral forests in the stem-exclusion stage (Cohort 1); multi-stage harvesting for mid-seral forests in the canopytransition stage (Cohort 2); and selection systems for late-seral forests in the canopy-gap stage (Cohort 3). In both variable rotations and the multi-cohort approach horizontal and vertical structural diversity, as well as inputs of large cavity trees and coarse woody debris are retained to various degrees depending upon details of the silvicultural interventions and rotation periods. By controlling these factors, it is hypothesized that the attributes and processes of a natural forest, including those of older forests, are maintained on the managed landscape.

It is important to quantify the economic tradeoffs involved with shifting from a forest management approach from that developed under the assumption of a short fire cycle to an approach that incorporates landscape forest patterns based upon a long fire cycle. Thus, while incorporating variable rotations and/ or the multi-cohort approach into forest management may meet ecological objectives, it is imperative to quantify the impact on wood supply. The annual harvest rate inevitably declines when a traditional even-aged silviculture with a targeted regulated forest on short (i.e., <100 year) rotations shifts to incorporate the maintenance of older age classes, including mid- and lateseral forests. For example, Fall et al. (2004) reported that a harvest rate of $65 \%$ of maximum harvest (regulated forest on a rotation age of 100 years) maintains harvest levels and older stand age classes compared to extended rotations without fire reductions. However, an analysis has yet to be done using an operational forest management plan that even currently includes some regulated constraints on the maintenance of old-growth targets and protected forested areas. In addition, the knowledge requirements involved in this shift have not been documented since, currently, forest management in northeastern Ontario makes use of even-aged silviculture systems (i.e., clearcutting), and wood supply models are constructed and calibrated using even-aged inputs. Thus, the applicability of the modeling tools developed for even-aged forest management when applied to modeling approaches that target mid- and late-seral forests requires assessment.

The first objective of this paper is to analyze and quantify the impact on wood supply under an actual forest management planning scenario. Here, we undertake a wood supply modeling exercise to answer two questions:

1. What is the difference in volume harvested, length of the road system, and relative cost between the current forest management plan harvest levels and a scenario based upon extended rotations?

2. What is the effect of including partial harvesting in a multicohort framework on current harvest levels, road length, and relative cost?

The second objective is to assess the applicability of current modeling input tools that were developed for even-aged management scenarios, and to propose adjustments for key model input variables, especially as they applied to older-aged 
conditions. These objectives were addressed by comparing the results of wood supply modeling based upon extended variable rotations and multi-cohort management to an approved forest management plan (before implementation, all forest management plans in Ontario must be approved by the Ontario government) developed using a spatial optimization model called Patchworks (Spatial Planning Systems, Deep River, Ontario, Canada).

\section{Methods \\ Study area}

Our study area was the 1.9-million-ha Gordon Cosens Forest Management Unit (FMU) in northeastern Ontario, Canada located in the Lake Abitibi Ecoregion (Crins et al. 2009). The climate in this Ecoregion falls within the Humid Mid-Boreal Ecoclimatic Region (Ecoregions Working Group 1989) and based upon the 30-year average (1971-2000) at Kapuskasing, Ontario (latitude $49^{\circ} 24^{\prime} \mathrm{N}$; longitude $82^{\circ} 28^{\prime} \mathrm{W}$; elevation $226.5 \mathrm{~m}$ ), the mean annual temperature is $0.7^{\circ} \mathrm{C}$ with 150.9 days with minimum temperature $>0^{\circ} \mathrm{C}$, and the mean annual precipitation is $831.8 \mathrm{~mm}$ (Environment Canada, National Climate Data and Information Archive, Canadian Climate Normals 1971-2000: [ww.climate.weatheroffice.gc.ca]). The area is part of the Precambrian Shield and is underlain by granitic or gneissic bedrock, with some areas of less acidic metavolcanic and metasedimentary rock (Crins et al. 2009). Most of the study area is located on the Clay Belt portion of this ecoregion, which is characterized by deep glaciolacustrine sediments of former post-glacial Lake Barlow-Ojibway and morainal calcareous clays and silts. The ecoregion also has extensive low-lying areas overlain by organic deposits (Boissonneau 1966). Elevation ranges from $132 \mathrm{~m}$ to $535 \mathrm{~m}$, decreasing from south to north. The forested area of the FMU is dominated by lowland black spruce (Picea mariana [Mill.] BSP) (32\%), poorly drained swamps (10\%), mixed upland transitional conifer (23\%), and transitional mixedwoods (18\%), aspen (Populus tremuloides Michx.) and white birch (Betula papyrifera Marsh.) (12\%) and minor amounts of pines (Pinus banksiana Lamb., P. strobus L., $P$. resinosa Ait.) (OMNR 2005).

The study area, which is $93 \%$ Crown land and $7 \%$ private Land, is made up of 1747500 ha of productive forest land, 184000 ha of non-productive forest and 85400 ha of non-forested (e.g., water, grass and meadow, unclassified, and agricultural land). The landbase also includes 15800 ha of parks, conservation reserves, and other protected areas. According to the Forest Resource Inventory (OMNR 2005) in 2005, $36 \%$ of stands were $>100$ years of age, $23 \%$ were regenerating $(<20$ years of age), and $41 \%$ were 20 to 100 years of age. Approximately $14 \%$ of the FMU has some harvesting restriction applied (not including riparian buffers), ranging from no harvest in reserves (15 $800 \mathrm{ha})$ to areas designated for American Marten (Martes americana Turton) cores ( 195000 ha).
The FMU experienced three major historic fire periods in 1850, 1895 and 1904, which produced areas of even-aged stands, but has had very little fire activity since. Forest management began on the forest in the 1920s in the form of horse-based logging operations; mechanized operations began in 1963 (OMNR 2005). Uncontained spruce budworm (Choristoneura fumiferana Clemens) outbreaks during 1940s, mid- to late 1970s, and early 1980s (Fleming et al. 2000) constitute another major disturbance that has occurred on the landbase.

The 2005 GIS Forest Resource Inventory (FRI) for the Gordon Cosens Forest was originally based upon interpretation of 1:15 840 and 1:20 000 color photos undertaken in 1986. Since 1986 , occurrences of harvest operations and natural disturbances (fire, windthrow, insect outbreaks) have been added to the forest resource inventory. Age and height of undisturbed stands have also been updated to reflect a condition in 2005; however, for stands that have been undisturbed since 1985, canopy composition has been assumed to be constant (i.e., succession since 1985 has not been incorporated).

\section{Model adjustments for incorporating older stand age classes} Current forest management estate modelling in boreal Ontario generally relies on an assumption of an even-aged ecosystem driven by fire; therefore the inputs (e.g., forest inventory, yield curves, succession) are aimed at even-aged forest management scenarios. The following describes the current process of calculating an allowable harvest but is a simplified summary of the actual process. For more details, readers are referred to the Forest Management Planning Manual (OMNR 2009) and the Analysis Package of the Gordon Cosens Management Unit Forest Management Plan, 2005-2010 (OMNR 2005). First, individual stand polygons in a Forest Resource Inventory (FRI) are assigned to one of 14 tree species groupings (Fig. 1). In northeastern Ontario, these groupings are based upon Standard Forest Units (SFU) (Parton et al. 2006) representing forest types with tree species and broad site similarities (Table 1). Associated with each SFU is a yield curve (Penner 2008, Penner et al. 2008, Sharma et al. 2008), which currently assumes that the stand originated from either a stand-replacing fire or clearcutting. Yield curves are adjusted to reflect

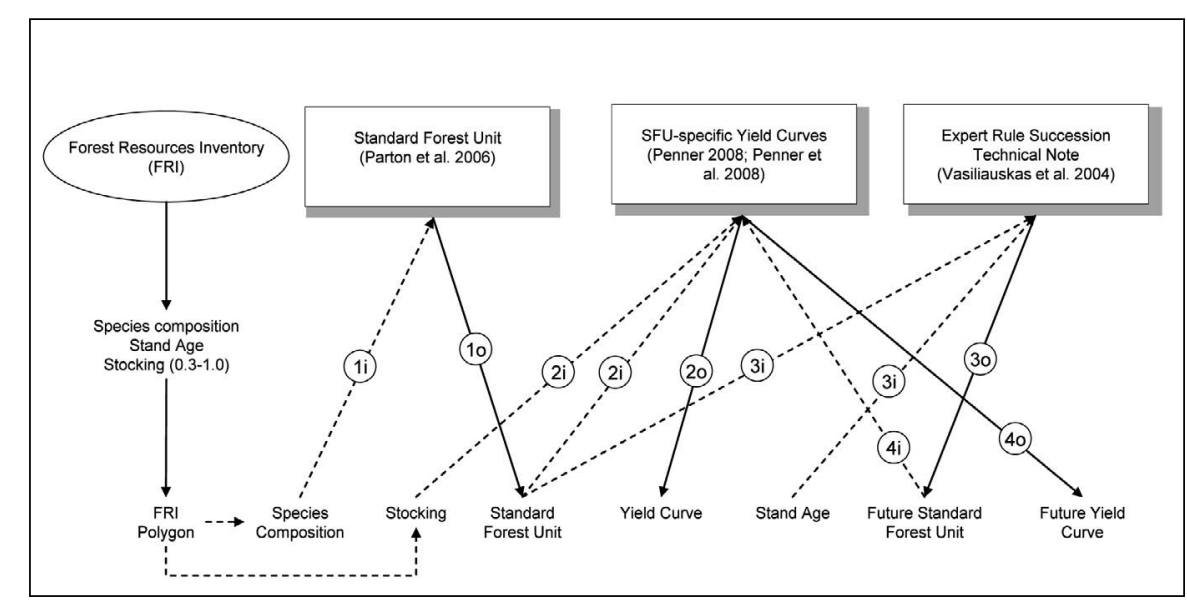

Fig. 1. Illustration of the current procedure for developing inputs (dashed lines; i) and outputs (solid lines; o) for various forest management tools (standard forest units, yield curves, succession rules) used within the wood supply model. Input-output pairs have the same number. 
Table 1. Standard Forest Unit (SFU) descriptions and average tree species composition representing the forest types with similar tree species and broad site characteristics (Parton et al. 2006). Individual stand polygons in a forest inventory are amalgamated into groupings based upon the SFU for calculation of an allowable harvest level in wood supply modeling. $\mathrm{Pj}$ = jack pine (Pinus banksiana Lamb.); Pw = white pine (Pinus strobus L.); Sb = black spruce (Picea mariana [Mill.] BSP); Sw = white spruce (Picea glauca [Moench] Voss); Po = trembling aspen (Populus tremuloides Michx.) or balsam poplar (Populus balsamifera L.); Bw = white birch (Betula papyrifera Marsh.); Bf = balsam fir (Abies balsamea (L.) Mill.); $C e=$ eastern white-cedar (Thuja occidentalis L.); La = eastern larch (Larix laricina [Du Roi] K. Koch). Only the major SFUs used in the Gordon Cosens forest management plan are listed.

\begin{tabular}{|c|c|c|c|}
\hline $\begin{array}{l}\text { Standard } \\
\text { Forest Unit }\end{array}$ & Abbreviation & Description & Average Species Composition \\
\hline Jack Pine 1 & PJ1 & Even-aged, fire origin jack pine stands & Pj 80\%; Sb 10\%; (Po, Bw) 10\% \\
\hline Jack Pine 2 & PJ2 & $\begin{array}{l}\text { Even-aged mixed jack pine stands due to stand age } \\
\text { approaching the transition stage }\end{array}$ & Pj 60\%; Sb 20\%; Po 10\%; Bw 10\% \\
\hline Poplar & PO1 & Even-aged, fire origin aspen stands & Po 70\%; Bw 20\%; (Sb, Pj, Sw, Bf) $10 \%$ \\
\hline Spruce & SP1 & Upland spruce stands originating from fire & $\begin{array}{l}\text { Sb } 50 \% \text {; Pj 20\%; Bw 10\%; Po } 10 \% \\
\text { (Bf, Sw, Ce, Pw) } 10 \%\end{array}$ \\
\hline White Birch & BW1 & Even-aged, fire origin white birch stands & $\begin{array}{l}\text { Bw 50\%; Po 20\%; Sb } 10 \% \\
\text { (Sw, Bf, Pj, Pw, Ce) } 20 \%\end{array}$ \\
\hline Mixedwood 1 & MW1 & Fire origin mixedwood aspen-jack pine stands & $\begin{array}{l}\text { Po } 30 \% ; \text { Pj } 30 \% \text {; Bw 20\%; Sb 10\%; } \\
\text { (Sw, Bf) } 10 \%\end{array}$ \\
\hline Mixedwood 2 & MW2 & $\begin{array}{l}\text { Either fire origin stands or succession mixedwood } \\
\text { stands. The latter is indicated by the greater presence } \\
\text { of balsam fir. }\end{array}$ & $\begin{array}{l}\text { Bw } 30 \% ; \text { Sb } 20 \% \text {; Po 20\%; Sw } 10 \% \text {; } \\
\text { Bf } 10 \% ;(\mathrm{Ce}, \mathrm{Pw}, \mathrm{Pj},) 10 \%\end{array}$ \\
\hline Spruce-Fir & SF1 & $\begin{array}{l}\text { Spruce dominates on stands originating from fire; } \\
\text { balsam fir dominates succession stands; cedar is } \\
\text { present late in succession }\end{array}$ & $\begin{array}{l}\text { Sb } 30 \% \text {; Bf } 20 \% \text {; Bw 10\%; Sw 10\%; } \\
\text { Ce 10\%; (Po, Pw, Pj, La) 20\% }\end{array}$ \\
\hline Black Spruce & SB1 & $\begin{array}{l}\text { Lowland (wet) sites common on the claybelt. Stands } \\
\text { can be either even-aged or uneven-aged }\end{array}$ & Sb 90\%; (La, Ce, Bw, Bf, Po) 10\% \\
\hline Lowland Conifer & $\mathrm{LC} 1$ & $\begin{array}{l}\text { Lowland (wet) sites usually associated with later } \\
\text { succession. }\end{array}$ & $\begin{array}{l}\text { Sb 50\%; Ce 30\%; La 10\%; (Bw, Bf, Sw, } \\
\text { Pj, Po) } 10 \%\end{array}$ \\
\hline
\end{tabular}

stocking. Succession is modeled through a set of expert-derived succession rules (Vasiliauskas et al. 2004), where the SFU and stand age are input into this expert rule set to derive a future succeeded SFU (an example of one set of rules is given in Table 2). Although these expert-derived succession rules were heuristically derived from expert opinion, the succession literature available at that time (Bergeron and Dubuc 1989; Bergeron 2000; Harper et al. 2002, 2003) and some initial analysis of the data reported in Taylor and Chen (2011) were used to help derive the heuristic rules. A data set and analysis to validate these rules does not exist at this time. The succeeded SFU is then assigned an even-aged yield curve since currently yield curves have been primarily developed for evenaged conditions (Fig. 2). The future age of the succeeded SFU is mostly a younger age where succession is modeled through transition to younger stand ages on respective even-aged yield curves. For example, by the rule for succession. set of Vasiliauskas et al. (2004) (Table 2) one succession trajectory occurs when a 140-year-old aspen stand (PO1) succeeds to a mixedwood stand (MW2) and is assigned a yield curve associated with MW2 at an age of 60 years; the mixedwood stand then succeeds to a spruce-fir stand at 140 years and is assigned a

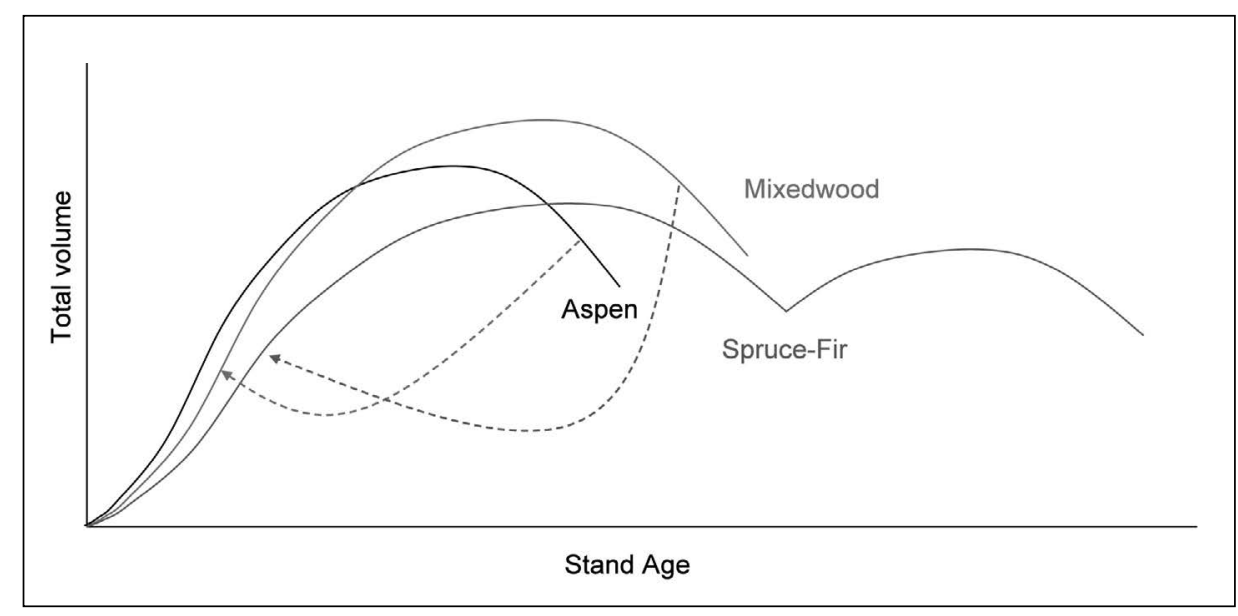

Fig. 2. An example using a succession trajectory of aspen to mixedwood to a spruce-fir forest type illustrating the current procedure for linking yield curves to succession rules. Solid lines represent the yield curve and dashed lines represent how yield curves are connected to account 
yield curve associated with SF1 at an age of 60 years; the sprucefir stand then remains in the all-aged condition and is assigned a yield curve associated with SF1 at an additive age. As illustrated in this example, SFUs that represent mid- to late-succession stage, the future age simply continues from the original age (SF1, SB1 in Table 2). The condition where SF1 succeeds to SF1 represents the all-aged late succession stage where gap dynamics dominate. The allowable harvest of the original Gordon Cosens forest management plan (FMP; OMNR 2005) was calculated with the spatially explicit harvest scheduling model Patchworks (Moore and Tink 2008, Rouillard and Moore 2008) using these types of even-aged tools that are developed and approved by the Ontario Ministry of Natural Resources.

For areas with short fire cycles, canopy species replacement or transition at older ages at the stand level is not a major concern since in most cases fire would reinitiate succession before transition occurs. Consequently, sample plots used to develop yield curves were historically targeted for even-aged stand conditions, since short-rotation, even-aged management was the goal. However, because older, uneven-aged forest types are more common in areas with long fire cycles, yield curves that incorporate succession become necessary for modeling extended rotations well beyond the age of onset of succession. Since inputs and tools used in current wood supply modeling are intended for use under even-aged management rules, we made several adjustments to the primary modeling inputs to allow incorporation of older stand age classes and partial harvesting. Model input adjustments were made for: 1) the forest inventory, 2) Standard Forest Unit, yield curves and succession; 3) multicohort definitions; and 4) partial harvesting. While the scientific literature has providing considerable insight and information regarding natural stand- and landscape-level dynamics in this region, the literature results are not in a form directly transferable to Ontario's wood supply models. Consequently, similar to the development of succession rules of Vasiliauskas et al. (2004), the literature was used as background information to make required input adjustments from expert opinion to develop input tools that are useable within the specific requirements of the wood supply models used here. For example, although published yield curves for black spruce from adjacent Québec are available (Garet et al. 2009), the algorithms are based on species and site index that cannot be directly used in Ontario's wood supply modeling. In Ontario, yield algorithms are based on forest unit and site class as derived through Plonski (1981). However, the literature does provide the basic knowledge from which the heuristic method is based.

The following describes the process required to modify the even-aged process of developing SFUs, yield curves, and succession in order to calculate an allowable harvest that not only incorporates but targets mid- and late-seral succession stages (Fig. 3).

\section{Forest Resource Inventory adjustments}

The stand age listed in the Forest Resources Inventory was adjusted to reflect time since disturbance age (TSD-age) using the following procedure. The original assignment of FRI forest stand polygons into the Northeast Region Standard Forest Unit (SFU) classification (Parton et al. 2006) did not explicitly separate even-aged and uneven-aged stands. Therefore, for our analysis we adjusted forest units to reflect the addition of uneven-aged stands. The current FRI does not identify stands that have succeeded from some initial seral stage into their current state. Thus, a mixedwood (aspen-spruce) stand that initiated from a fire event is identified as the same as a mixedwood stand that has evolved from an aspen-dominated stand. Since the ages associated with the FRI captures the age of the current living trees, these later successional stands may have a photo-interpreted age that is less than the actual time since last disturbance (Fig. 4).

Accordingly, we developed adjustments to the FRI to identify stands that had likely developed through one or several succession stages. Such stands were identified based upon a rule set derived from local expert knowledge. This rule set was based on a combination of the historical harvesting record for harvested polygons, and the absence/presence of obligate early and late succession tree species and stocking, augmented by succession literature for natural polygons. Under this rule set (see Box 1), stands dominated by tree species that are early-successional, shade-intolerant species (aspen, jack pine, and/or white birch) were assumed to be of direct fire origin (based upon Ilisson and Chen 2009) and the FRI age was used. Stands with shade tolerant species (balsam fir [Abies balsamea (L.) Mill.] and $\geq 10 \%$ eastern white cedar [Thuja occidentalis L.] were assumed to result through succession (based upon Bergeron and Dubuc 1989, Bergeron 2000). Mixedwood (see Chen and Popadiouk 2002 for a definition), upland spruce (black spruce and white spruce

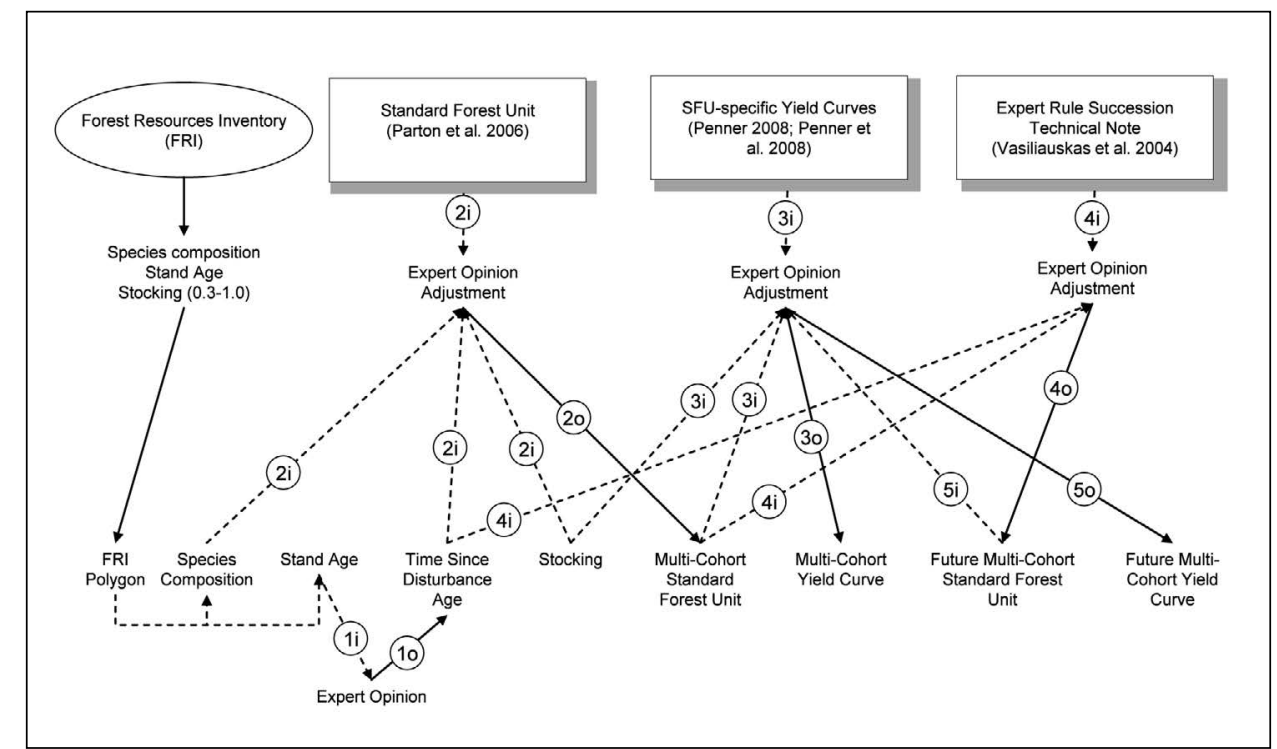

Fig. 3. Illustration of the procedure needed to modify inputs (dashed lines; i) and outputs (solid lines; o) in order to incorporate and target mid- and late-seral succession states into the wood supply modeling analysis. Input-output pairs have the same number. 


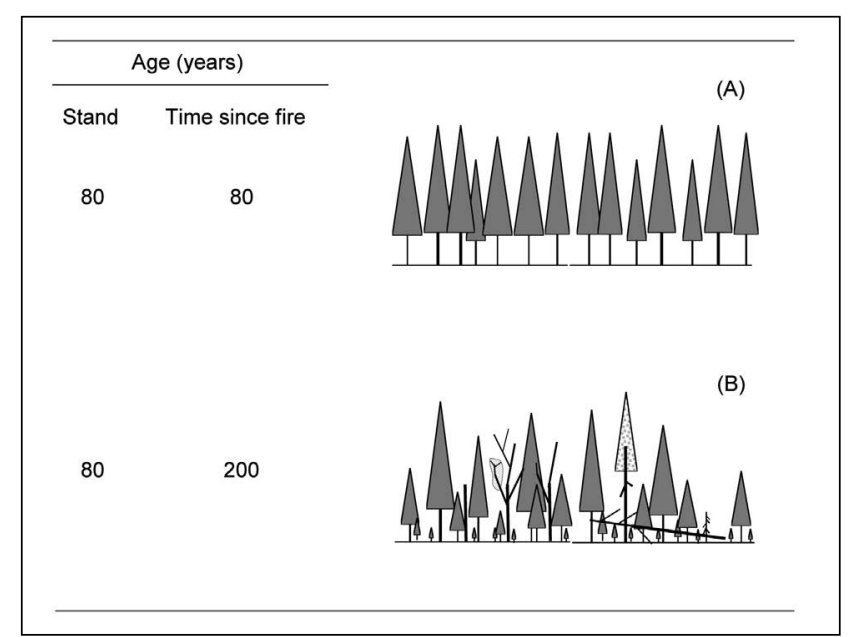

Fig. 4. Under the current Forest Resources Inventory (FRI) both stands $(A)$ and $(B)$ would be assigned the same stand age. However, the latter has developed through succession, thus has a variety of structure and inputs of coarse woody debris during २०० years of stand development.

[Picea glauca (Moench) Voss.]) and lowland black spruce stands can result from either fire origin or through canopy succession (based upon Chen et al. 2009, Paré and Bergeron 1995 for mixedwoods and Harper et al. 2003, 2005; Garet et al. 2009 for black spruce). Mixedwood stands where trembling aspen was dominant or where trembling aspen and spruce were in equal proportions were considered fire origin stands; where white birch exceeded trembling aspen or where cedar was present were considered succession origin (based upon Bergeron 2000). Upland spruce stands with the presence of cedar were considered successional in origin (based upon Bergeron and Dubuc1989, Bergeron 2000). Lowland black spruce stands with $>70 \%$ stocking were considered fire origin, whereas lower stocked stands were considered succession origin. A decrease in basal area of black spruce stands on clay soils is correlated with time since fire due to a combination of factors associated with older black spruce stands, which include increased windthrow, root rot and/or paludification (Harper et al. 2003, 2005). The cut-off of $70 \%$ was based upon local expert opinion.

The identified succeeded stands were then aged based on regional succession rules (Vasiliauskas et al. 2004) by using the average age of succession. For example, a MW2 SFU may have a photo-interpreted age of 75 years but was identified through our rule set to be a successional mixedwood from a poplardominated stand (PO1). In this case, the stand was age-adjusted based upon the midpoint of succession based on Vasiliauskas et al. 2004. Thus, we assumed that the 75-year-old photointerpreted stand had actually succeeded at an average age of 140 years (see Table 2) to a 60-year-old MW2 stand. This succeeded 75-year-old mixedwood stand then existed as an aspen-dominated stand for 140 years followed by a mixedwood stand for 15 years (i.e., after succession from aspen the stand was a 60-year-old mixedwood; therefore, now at 75 years old the stand existed as a mixedwood stand for the last 15 years). Thus, we calculated the time since fire as 155 years (Table 3). A new age field was added to the Patchworks spatial dataset assigning a time since disturbance (years) to each forest polygon.

\section{Box 1}

Adjustments made to the Forest Resources Inventory (FRI) to capture age of succeeded stands. Standard forest unit designations are according to Parton et al. (2006) and are briefly described in Table 1.

1. FRI polygons with a recorded clearcut harvest origin are assigned the FRI age.

2. FRI polygons with jack pine, white birch or aspen leading are assigned the FRI age.

3. FRI polygons where aspen and spruce combined are leading but in equal proportions (e.g., $\mathrm{At}_{4} \mathrm{Sw}_{4} \mathrm{Bf}_{2}$ ) are assigned the FRI age.

4. Lowland spruce stands where the stocking is $>0.7$ are assumed to be fire origin and assigned the FRI age.

5. FRI polygons that are MW2 after application of rules 2 and 3 above are assumed to be successional mixedwoods, and are assigned a TSF age based upon the application of succession ages from Vasiliauskas et al. (2004). Thus, PO1 succeeds to 60-year-old MW2 starting at 120 years and ending at 170 years. If we pick a mid-point of succession at 140 years, add 140 years to the difference of FRI age -60 years.

6. MW2 polygons that contain cedar are assumed to be late successional mixedwoods that either are at the end change age or have gone through at least one mixedwood to mixedwood transition. Add 170 years (end change age for PO1 to MW2) to the difference of FRI age -60 years.

7. FRI polygons that are SF1 are assumed to be late succession stands that have gone through the succession sequence of PO1 to MW2 to SF1. If we use the age sequence PO1 succeeds to 60-year-old MW2 at 140 years and then succeeds to 60-year-old SF1 in another 30 years (estimated), then add 170 years to the difference of FRI age - 60 years.

8. Lowland spruce stands where the stocking is 0.3 to 0.7 are assumed to be successional stands and are assigned an age of 200 years based upon the onset of old growth for organic soils on the Lake Abitibi Model Forest and adjacent Quebec forests (Harper et al. 2003).

9. Lowland cedar stands are assumed to be successional stands that have gone through SB1 stands at an age of 200 years (start change is 160 and end change is 250 years) thus we add 200 years to the FRI age.

Table 2. Example of succession rules used in Ontario's wood supply modeling (Vasiliauskas et al. 2004). SFU = Standard Forest Unit as defined in Table 1.

\begin{tabular}{lccc}
\hline $\begin{array}{l}\text { Current } \\
\text { SFU }\end{array}$ & $\begin{array}{c}\text { Succeeded } \\
\text { SFU }\end{array}$ & $\begin{array}{c}\text { Change age } \\
\text { (years) }\end{array}$ & $\begin{array}{c}\text { Future age } \\
\text { (years) }\end{array}$ \\
\hline PO1 & MW2 & 140 & 60 \\
MW2 & SF1 & 140 & 60 \\
SF1 & SF1 & 140 & same age \\
SB1 & LC1 & 200 & same age \\
\hline
\end{tabular}


Table 3. The rule set used for extending age of operability used in the current Forest Management Plan for the extended rotation modelling scenario.

\begin{tabular}{lcc}
\hline SFU & $\begin{array}{c}\text { Original lower } \\
\text { operability range }\end{array}$ & $\begin{array}{c}\text { Extended lower } \\
\text { operability range }\end{array}$ \\
\hline BW1 & 60 & 95 \\
LC1 & 90 & 175 \\
MW1 & 70 & 105 \\
MW2 & 70 & 105 \\
PJ1 & 60 & 100 \\
PJ2 & 60 & 105 \\
PO1 & 70 & 95 \\
SB1 & 90 & 190 \\
SF1 & 60 & 105 \\
SP1 & 70 & 125 \\
\hline
\end{tabular}

through senescence and are occupied by saplings and polesized stems). Cohort 3 is the perpetuation of the uneven-aged condition of Cohort 2, except to an all-aged condition with few remaining intolerant species and more recruitment of snags and downed woody debris. All cohort designations were defined for the newly created yield curves. The first peak generally represents the condition of Cohort 1 succeeding to Cohort 2, and curves were smoothed to represent Cohort 2 succeeding to Cohort 3 (Fig. 5A).

\section{Incorporation of partial harvesting}

Finally, current wood supply models used in boreal Ontario do not consider forms of partial harvesting that result in uneven-aged stand conditions (e.g., irregular shelterwood, selection system). Partial harvesting in uneven-aged stand conditions is not explicitly incorporated into current boreal wood

\section{Standard Forest Unit, yield curve and succes- sion modifications}

Succession forest units were added to the Standard Forest Unit designations to account for those forested polygons that were assessed as originating through succession in the FRI exercise above. Succession BW1, MW1, MW2, SP1, $\mathrm{Pj} 2, \mathrm{SF} 1, \mathrm{SC} 1$, and SB1 Multi-Cohort Standard Forest Units (MC-SFU) were added based upon species composition, TSD-age, and stocking. Yield curves then had to be derived for the succession standard forest units based upon the provincial even-aged yield curves and adjusted by expert opinion to form MC-SFU yield curves. From a combination of the MC-SFU and stocking a yield curve is assigned to each MC-SFU. In the realm of spatial modelling within Patchworks, each stand requires a deterministic succession trajectory. Succession takes place through a set of rules where MC-SFU and TSD-age are used to derive a future MC-SFU. The future MC-SFU is then assigned an uneven-aged succession multicohort yield curve (MC-SFU yield curve). In the modeling the MC-SFU and associated MC-SFU yield curve are assembled together to form a continuous yield curve for a 350-year period (see Fig. $5 \mathrm{~A})$ representing a whole succession sequence. This connecting of yield curves was done using the expert-derived succession rules of Vasiliauskas et al. (2004) and a group of regional growth and yield experts.

\section{Multi-cohort definitions}

Three cohorts were defined for this project using the stratified forest units and age ranges as criteria. In general, Cohort 1 represents a stand that originated from a stand-replacing event (i.e., fire or clearcutting) which is characterized as an even-aged stage. Cohort 2 represents the succession of the even-aged stand into an uneven-aged (approximately two or three ages within a stand where canopy gaps are created

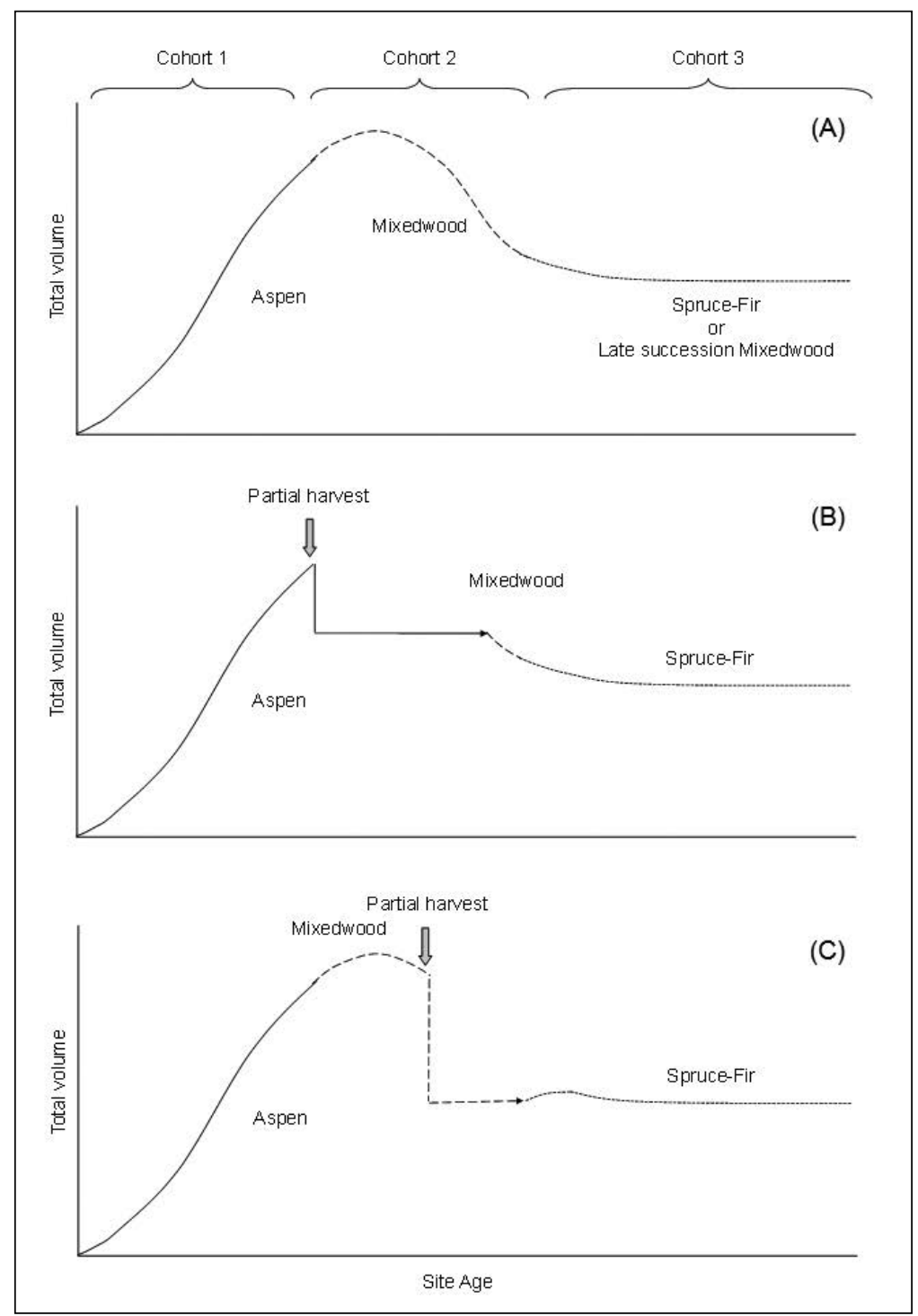

Fig. 5. Yield curves (solid line) were assembled for a 350 -year period by stringing yield curves representing succession Standard Forest Units to represent a whole succession sequence for a stand condition (A). In order to simulate the effects of partial harvesting on yield and succession, we simply modeled an acceleration of succession (B and $\mathrm{C}$ ). If harvesting occurs at the points in time indicated by the arrows, then the future point on the yield curve simply "jumped" ahead (dashed line). 
supply modeling in Ontario. Accordingly, we developed a simple method to incorporate partial harvesting that works for the even-aged modeling tools used in boreal Ontario. Similar to the manner in which wood supply models account for commercial thinning, we "partial harvested" at a point on the yield curve determined to allow for movement towards an older cohort and then simply "accelerated succession" further along the curve to the next cohort (Fig. 5B and Fig. 5C). With this method, partial harvesting is not necessarily targeting stand structure as in a planned selection system nor replacing non-stand-replacing disturbance events (moderate windthrow, insect outbreaks causing variable mortality, senescence), but rather assumes that non-stand-replacing disturbance events are inevitable and that we are harvesting a portion of the overstory that would eventually be removed through natural mortality.

\section{Scenario design and analysis}

To explore and compare four management scenarios, we used the GIS-based, spatially explicit harvest scheduling model Patchworks (Moore and Tink 2008, Rouillard and Moore 2008). In the context of the current project, Patchworks' ability to develop spatially explicit harvest allocations that achieve a broad range of conflicting goals using a goal programming framework was important. Four scenarios were developed to explore the alternative forest management practices and forest conditions:

1. Status Quo: The yield modeling from an operational Forest Management Plan approved by the provincial government through its regulatory framework was remodeled using the uneven-aged Multi-Cohort SFU and Multi-Cohort Yield Curves. There were little differences in modeled output between the original model with even-aged inputs and the adjusted model.

2. Multi-Cohort targets: Landscape-level area targets for Cohorts 1, 2 and 3 were applied to the Status Quo scenario (1) at $50 \%, 25 \%$ and $25 \%$, respectively, which are the estimated proportions of cohorts expected for a fire cycle of 170 years (Bergeron et al. 1999, 2001).

3. Extended Rotations: the ages at which harvesting could occur were lengthened from the Status Quo scenario to the age when each stand begins to transition into or has become a Cohort 2 or 3 stand. Traditionally, operability limit is the average age per SFU when the stand reaches a minimum threshold for merchantable volume and product specifications (sawlogs vs. pulpwood). By increasing the age of operability so that a stand can be harvested closer to this age of transition, it was predicted that the model would better achieve the landscapelevel cohort targets.

4. Partial Harvesting: Scenario 2 was re-modeled with the introduction of partial harvesting. Partial harvesting occurred in Cohort 2 on all stands having the 350-year-old yield pattern illustrated in Fig. 5A.

Each of the scenarios used a common set of harvest and transportation costs objectives in order to compare differences between scenarios.

We report on a time frame from 2005 to 150 years into the future with comparisons between the scenarios for: 1) meeting each of the 3 cohort targets; 2 ) annual and total merchantable volume harvested; 3) new road length; and 4) relative total cost delivered to the mill. The target for Cohort 3 had to be heavily weighted within Patchworks in order to essentially force the model results to not harvest younger aged stands to meet the Cohort 3 target. Harvesting costs are based upon actual values supplied by the industry but only relative harvesting costs are reported here since actual costs are private-sector proprietary information not shared with the public. Partial harvesting was not modeled for cost since currently in boreal Ontario partial harvesting is not practised; therefore, information on cost is unavailable.

We did not include fire occurrence in the model, so if our assumption of effective fire suppression is wrong additional stand-replacing disturbances other than clearcutting can be expected (Fall et al. 2004). However, in Ontario if large fires that have an impact wood supply occur, the wood supply modelling is redone.

\section{Results \\ Multi-cohort targets}

The Cohort 1 target (50\% of managed landscape) was easily achieved in the Status Quo scenario with a mean of $71 \%$ over the time period, whereas Cohort 2 and 3 targets (both 25\%) had means of $19 \%$ and $10 \%$ (Fig. 6). The Cohort 2 target was met within the first 40 years of modeling, but all subsequent time periods were below the target and the Cohort 3 target was never attained.

Under the Multi-Cohort Target and Extended Rotations scenario, the Cohort 1 means were $58 \%$ and 53\%, respectively, with very little variation. As with the Status Quo scenario, a general decreasing trend in the amount of Cohort 2 was observed, with respective means of $24 \%$ and $26 \%$. Although the $25 \%$ target was not achieved after 60 years in either scenario, they maintained more area of Cohort 2 stands over the modeled time frame than the Status Quo harvesting scenario.

Under the Multi-Cohort, Extended Rotations and Partial Harvesting scenarios, the Cohort 3 target was achieved and maintained after 60 modeled years with a mean of $20 \%$ for all three scenarios, twice that of the Status Quo scenario.

\section{Wood supply}

Under the Status Quo scenario, which achieved all targets in the 2005 forest management plan for the study area, the predicted mean annual wood supply was $308000 \mathrm{~m}^{3}$ (Fig. 7). Under the Multi-Cohort Target scenario there was a mean decrease of $15 \%$, ranging from $2 \%$ to $27 \%$ for all periods. Under the Extended Rotations scenario there was a mean decrease of $40 \%$, ranging from $11 \%$ to $56 \%$ for all periods. The Partial Harvesting scenario gained about $50 \%$ of the difference in wood supply volume compared to the Multi-Cohort Target and Status Quo scenarios. In all scenarios, a dip in the wood supply during years 15 to 75 was observed, which can be attributed to an imbalanced age class structure and/or the spatial arrangement of harvestable stands in that time frame.

\section{Total road usage}

The spatially explicit model was able to record total road usage $(\mathrm{km})$, which included newly constructed roads and use of all roads for transporting wood volume to the mill (Fig. 8). Under the Multi-Cohort Target scenario, there was a mean increase of $21 \%$ in road usage with a $44 \%$ mean increase in usage of new roads compared to the status quo scenario. A similar trend was observed under the Extended Rotations scenario with a mean increase of $19 \%$ of total road usage and a $44 \%$ mean increase in new roads in order to achieve the wood supply in these scenarios. The Partial Harvest scenario again fell between the Status Quo and the Multi-Cohort Target scenarios. 


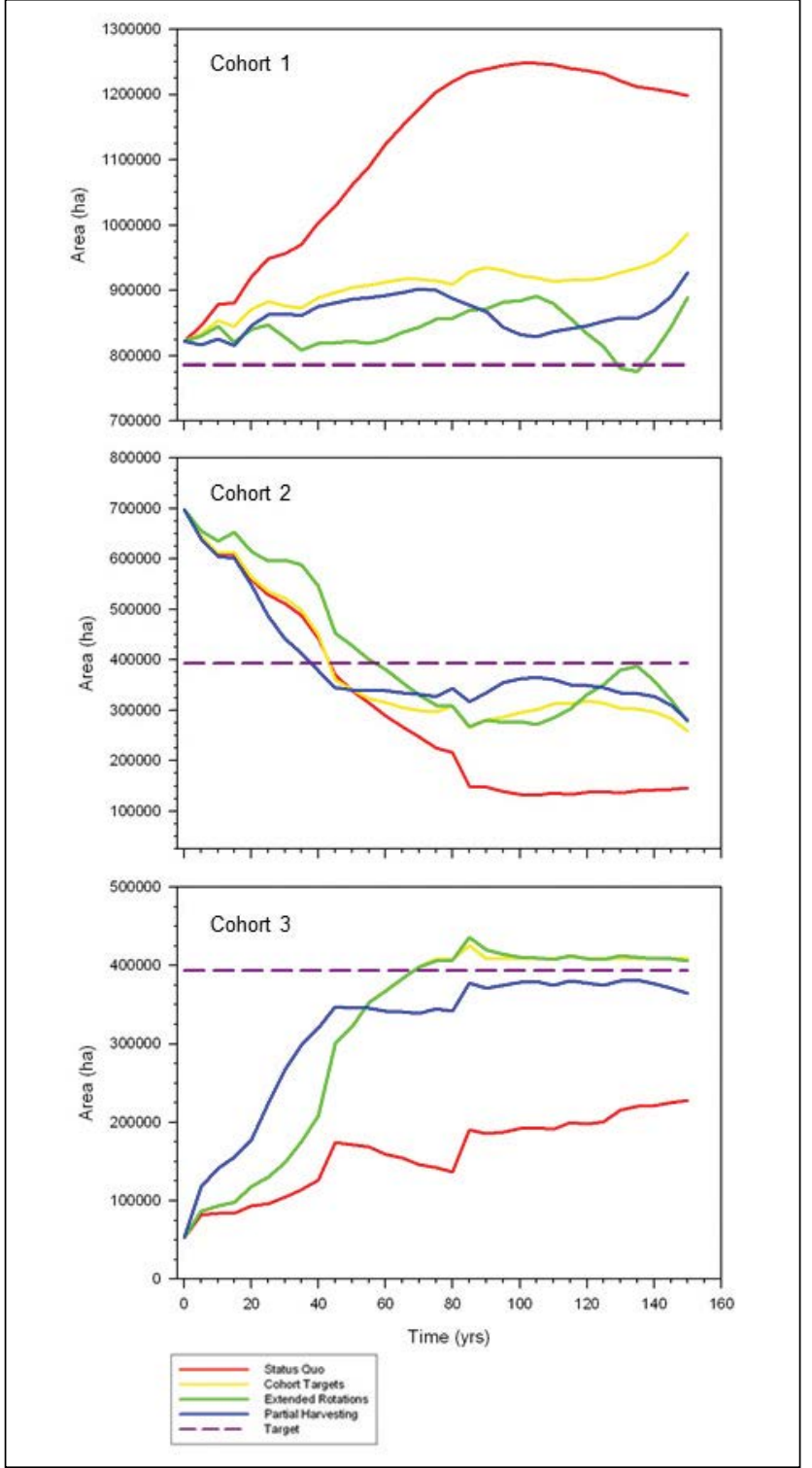

Fig. 6. Modeled changes in area for Cohorts 1,2 and 3 as defined in Fig. 4 over a 150-year period. The dashed line represents the target cohort area for each respective cohort that was given as an objective in the modeling. Area is given for five-year periods.

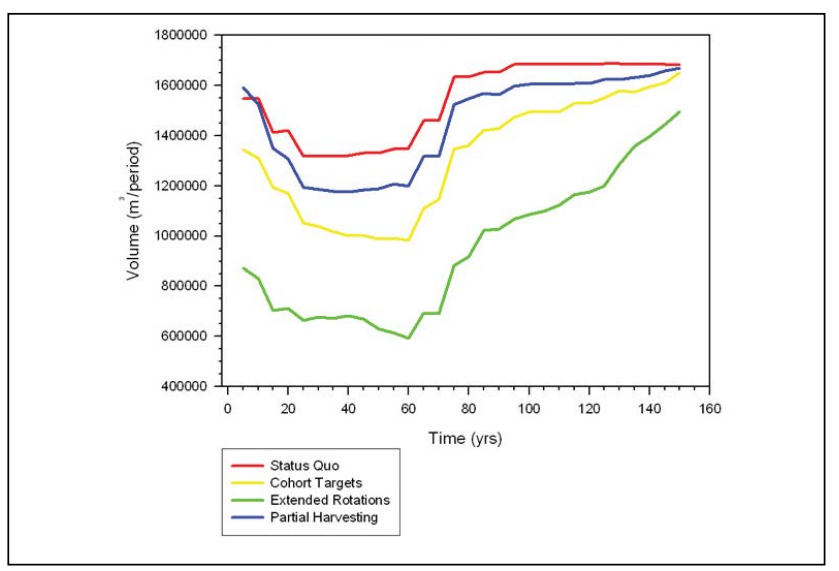

Fig. 7. Modeled available wood supply for harvest over a 150-year period. (Available volume over five-year periods.).

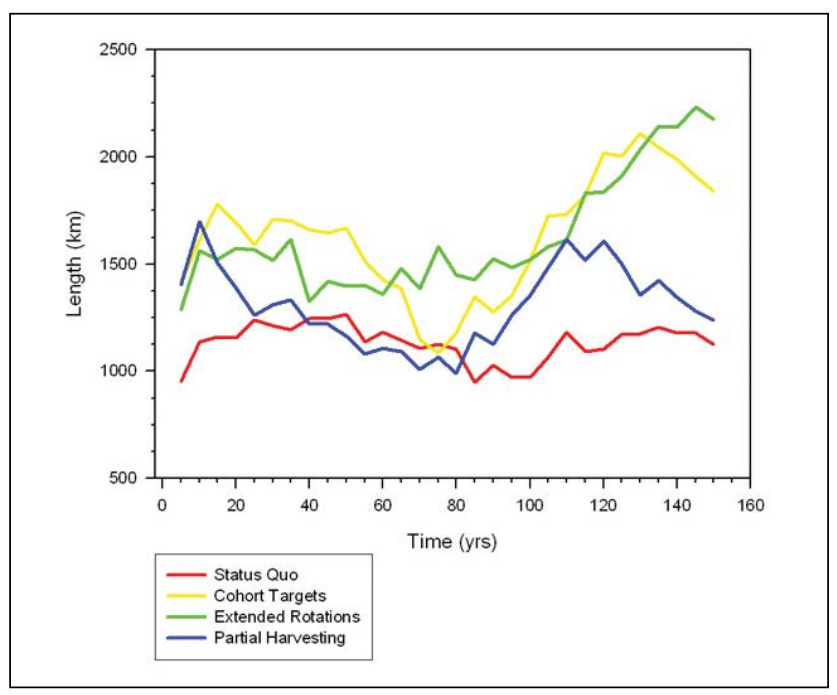

Fig. 8. Modeled total road usage of all roads used for transporting wood volume to the mill over a 150-year period. Length is given for five-year periods.

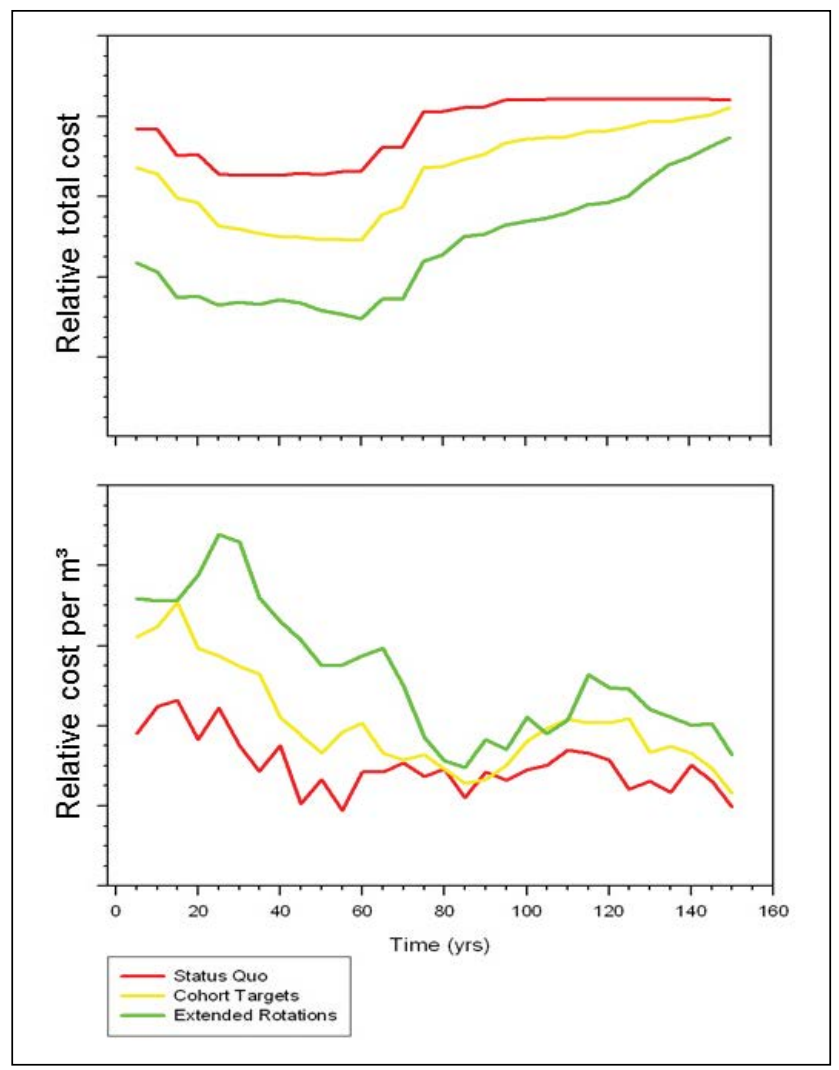

Fig. 9. Modeled relative cost of wood delivered to the mill over a 150-year period. 


\section{Relative harvest cost}

Except for a convergence in relative cost at about 80 years, the Status Quo scenario had the lowest harvest costs (Fig. 9). The Multi-Cohort Target and Extended Rotations scenarios had considerably higher costs per $\mathrm{m}^{3}$ although less total costs due to lower wood volumes harvested.

\section{Discussion}

Even with regulated constraints on the maintenance of old growth targets and protected area, it appears that current operational forest management planning will not meet older Cohort 3 targets as modeled in this paper. However, when planning for Cohort 3 targets by extending rotations there is a trade-off where although older cohort targets are met, there is a decrease in wood allocation and an increase in unit cost. By introducing partial harvesting into extended rotations some of the volume of available wood can be recovered compared to the status quo even-aged management. The lack of empirical, science-based inputs, particularly concerning successional patterns and volume yields in Cohorts 2 and 3, forced us to use model inputs derived from expert opinion. This modeling approach adds a degree of uncertainty to a forecasting exercise whose outcome is inherently uncertain (Drescher et al. 2008). Clearly, this lack of empirical information constitutes a barrier to building robust model scenarios that incorporate objectives that diverge widely from current even-aged forest management.

Given that the Status Quo scenario aims for a regulated, even-aged forest (Cohort 1) and that all other scenarios set minimal targets for Cohorts 2 and 3, it is not surprising that the Status Quo scenario had the least amount of area in Cohorts 2 and 3 to meet habitat and old growth directives. Clearly, in areas where there is a long natural fire cycle, "short rotation" forestry does not meet the directive concerning emulation of the natural disturbance pattern.

Extended rotations considerably reduced wood supply in comparison to short-rotation forestry. If the Cohort 2 and 3 targets had been based on the results of Cyr et al. (2010) for fire cycles of the claybelt where according to the variation in forest age structure $75 \%$ of the forest should be $>150$ years, extended rotations would be longer and wood supply further reduced.

Inclusion of partial harvesting substantially raised harvest volumes compared to extended rotations to a point just less than the short-rotation Status Quo scenario. Our partial harvesting scenario was fairly rudimentary in that we simply treated partial harvesting as working within non-stand-replacing events and accelerating succession. Unlike clearcutting, where we assume that fire suppression is effective and we are substituting clearcutting for stand-replacing fire, with the possible exception of major insect outbreaks, non-stand-replacing events are generally not suppressed. Our treatment of partial harvesting salvaged some mortality that eventually occurs due to natural ageing or other non-stand-replacing disturbance. If we had included more sophisticated techniques, such as boreal-adapted selection systems, managing for late-succession characteristics (DeBell et al. 1997, Burton et al. 1999, Keeton 2006), and/or converting even-aged stands to uneven-aged structures (Harvey et al. 2002, Kelty et al. 2003, Nyland 2003), volume available from partial harvesting would likely be higher than modeled here, yet maintain stand structures of Cohorts 2 and 3. Therefore, if the inclusion of partial harvesting maintains ecosystem function over the landscape, then multi-cohort management potentially represents a compromise between increased harvest levels and the maintenance of ecosystem function in regions with long natural fire cycles (Bergeron et al. 1999, 2001, 2002).

The amount of new roads modelled under the various scenarios was unexpected. We normally think of extended rotations as having the lightest ecological footprint, but it is likely that observed results in this scenario are influenced by the existing spatial forest composition. The concentrations of younger stands in close proximity to the centrally located mill and of older, unmanaged stands near or at the periphery of the landbase are clearly an outcome of the long history of forest management in the area. This starting condition forced the model to begin harvesting older stands at the periphery of the management area, which increased road usage. In addition, once a regulated forest is achieved in around 100 years, the road network is in place, whereas new roads will still be needed after this time in the extended rotation scenario. If older-age stands were more regularly distributed over the landscape, it is possible that new road length would be similar. Alternatively, if a more balanced distribution of older-age stands across the landbase was a specific objective, the new road length of the Status Quo scenario would likely increase to levels similar to those of the other scenarios.

The large discrepancy in relative cost likely reflects the costs of road-building and hauling distance to the mill. Scenarios 1 to 3 all use clearcutting exclusively for harvesting, so the only difference in harvest cost would be due to lower harvested volumes associated with older, late-succession age classes.

Although some of the parameter values appear to converge at the end of the modeling period, especially volume (Fig. 7), caution is needed in interpreting these results. Long simulation periods tend to produce results that are an artefact of modeling as modeled results increasingly reflect modeled inputs. In addition, because there are no objectives or constraints after the simulation period an "end-of-the-world" modeling artefact can affect the results as the time period approaches the end of the simulation period.

If future Forest Management Plans in areas with long natural fire cycles are required to maintain a higher proportion of older age classes under emulation of natural disturbance directives, then extended rotations or the multi-cohort system present favourable management approaches. We are certain that large areas of uneven-aged mixed wood, spruce-fir, and black spruce stands in mid- and late-seral stages are present within the landscape of northeastern Ontario, in particular within the claybelt (Bergeron and Archambault 1993; Bergeron et al. 2001, 2004; Lefort et al. 2003; Cyr et al. 2010). One critical question is whether the predominance of older age classes is due to effective historical fire suppression over a long enough time period to affect regional fire cycle (millions of ha). Martell and Sun (2008) correlated a reduction of fire area burned with level of fire suppression effort. However, whether the time period of effective historical fire suppression is enough and has occurred over a long enough period to allow the large increase in old forests across the landscape reported today is still highly questionable.

\section{Empirical Inputs Requirements}

Clearly, the lack of empirical and science-based information constitutes a barrier to building robust model scenarios that address older age classes on the landbase. In particular, forest inventory, yield curves and succession rules in formats that are operationally useable are required. As far as an inventory is concerned, Ontario is currently implementing a new digital FRI, 
which will include a field description for an interpreted even- or uneven- stand structure, a measure that should provide more accurate identification of Cohorts 2 and 3. In addition, while air photo interpretation for operational purposes will still be done at a 1:20 000 scale, the digital image can be enlarged to approximately 1:7000 scale, which could also enhance the ability to characterize Cohort 2 and 3 stands. In combination with LiDAR technology (Woods et al. 2011), these inventory tools should help meet the challenges of better identifying stands in mid- and late-seral stages of succession. In forest management scenarios where the maintenance of mid- and late-seral succession stages is important, the development of yield curves needs to consider replacing age with time-since-fire as suggested by Garet et al. (2009). Yield curves must then be linked to succession pathways. While succession is a well-researched topic (Yemshanov and Perera 2001), the difficulty lies in transferring the research into a useable form for current models used operationally. For example, Ontario succession rules are based on the older concept of multiple succession pathways (Cattelino et al. 1979) but only recently has an attempt been made to quantitatively bring this concept into boreal Ontario (Taylor and Chen 2011). In boreal Ontario, this lack of directly useable science forces operational inputs to be based on expert heuristic procedures (Vasiliauskas et al. 2004), which although indirectly make use of the scientific literature as background have yet to be scientifically verified. The convergence of these operational heuristically derived procedures with research derived information is needed.

Despite this obvious shortcoming, the lack of empirical information should not preclude consideration of alternative approaches aimed at maintaining older age classes within the landbase. Certainly, almost all forest management decisions could be seen to suffer, to some degree, from the same lack of complete scientific knowledge. For example, the succession rules used in the modeling here were based on a heuristic procedure (Vasiliauskas et al. 2004), which although relied on the scientific literature, has yet to be empirically validated. Yet this heuristic procedure forms the basis of forest management planning in boreal northeastern Ontario and is even further modified within specific plans based upon local knowledge. Currently, wood supply allocation and subsequent harvesting is ongoing in the realm of millions of $\mathrm{m}^{3}$ of wood, even with this uncertainty. Considerable research has been carried out in the claybelt region (Lefort et al. 2002), and the scientific evidence of natural long fire cycles associated with the claybelt of Ontario and Québec is strong (Bergeron et al. 2001, 2004). Moreover, this research highlights a number of shortcomings in current management approaches and raises questions that need to be addressed if emulation of the natural disturbance pattern is a goal. The modeling exercise presented here has the merit of illustrating the difference in landscape results between short-rotation, even-aged forestry, and forestry based on emulating relatively long natural fire cycles.

\section{Conclusion}

This study provides little doubt that application of alternative scenarios to short-rotation clearcutting to meet emulation of natural disturbance directives where there is a natural long fire cycle will result in a reduction of allowable harvest. Multi-cohort management, however, may represent a compromise between maximizing harvest levels and retaining mid- and late-succession habitat if partial harvesting can be demonstrated to maintain ecosystem function. It should also be noted that if extended rotations were considered the appropriate reference base for maintaining natural forest age structure in areas associated with long fire cycles, then the introduction of partial harvesting would actually increase the allowable harvest. Unquestionably, while short-rotation forestry maximizes harvest volumes and therefore tends to do a better job of meeting economic and many social values, it does appear to fall short in meeting ecological criteria of sustainability in areas associated with long fire cycles.

\section{Acknowledgements}

We thank Yves Bergeron, Université du Québec en AbitibiTémiscamingue and his collaborators for their research on fire cycles associated with northeastern Ontario's claybelt, and introducing the multi-cohort approach that forms the basis of this paper. We also thank Brian Harvey, Université du Québec en Abitibi-Témiscamingue, and Jay Malcolm, University of Toronto, for their reviews of an earlier draft; and two anonymous reviewers for their review of the submitted paper. Funding was supplied by the Ontario Ministry of Natural Resources, Science and Information Research Division.

\section{References}

Bergeron, Y. 2000. Species and stand dynamics in the mixed woods of Quebec's southern boreal forest. Ecology 81: 1500-1516.

Bergeron, Y. 2004. Is regulated even-aged management the right strategy for the Canadian boreal forest? For. Chron. 80: 458-462.

Bergeron, Y. and S. Archambault. 1993. Decrease of forest fires in Quebec's southern boreal zone and its relation to global warming since the end of the Little Ice Age. The Holocene 3: 255-259.

Bergeron, Y. and M. Dubuc. 1989. Succession in the southern part of the Canadian boreal forest. Vegetatio 79: 51-63.

Bergeron, Y., S. Gauthier, M. Flannigan and V. Kafka. 2004. Fire regimes at the transition between mixedwood and coniferous boreal forest in Northwestern Quebec. Ecology 85: 1916-1932.

Bergeron, Y., S. Gauthier, V. Kafka, P. Lefort and D. Lesieur. 2001. Natural fire frequency for the eastern Canadian boreal forest: consequences for sustainable forestry. Can. J. For. Res. 31: 384-391.

Bergeron, Y. and B. Harvey. 1997. Basing silviculture on natural ecosystem dynamics: an approach applied to the southern boreal mixedwood forest of Quebec. For. Ecol. Manage. 92: 235-242.

Bergeron, Y., B. Harvey, A. Leduc and S. Gauthier. 1999. Forest management guidelines based on natural disturbance dynamics: Stand- and forest-level considerations. For. Chron. 75: 49-54.

Bergeron, Y., A. Leduc, B.D. Harvey and S. Gauthier. 2002. Natural fire regime: A guide for sustainable management of the Canadian boreal forest. Silva Fennica 36: 81-95.

Boissonneau, A. 1966. Glacial history of northeastern Ontario: The Cochrane-Hearst area. Can. J. Earth Sci. 3: 559-578.

Burton, P.J., D.D. Kneeshaw and K.D. Coates. 1999. Managing forest harvesting to maintain old growth in boreal and sub-boreal forests. For. Chron. 75: 623-631.

Cattelino, P.J., I.R. Noble, R.O. Slatyer and S.R. Kessell. 1979. Predicting the multiple pathways of plant succession. Env. Manage. 3: 41-50.

Chen, H.Y.H. and R.V. Popadiouk. 2002. Dynamics of North American boreal mixedwoods. Environ. Rev. 10: 137-166.

Chen, H.Y.H., S. Vasiliauskas, G.J. Kayahara and T. Ilisson. 2009. Wildfire promotes broadleaves and species mixture in boreal forest. For. Ecol. Manage. 257: 343-350.

Crins, W.J., P.A. Gray, P.W.C. Uhlig and M.C. Wester. 2009. The ecosystems of Ontario, Part 1: Ecozones and Ecoregions. Ontario Ministry of Natural Resources, Inventory, Monitoring and Assessment Section, Peterborough, ON. Report SIB TER IMA TR- 01. $71 \mathrm{p}$.

Curtis, R.O. 1997. The role of extended rotations. In K.A. Kohm and 
J.F. Franklin (eds.). Creating forestry for the 21st century: The science of ecosystem management. pp. 165-170. Island Press, Washington, DC. 475 p.

Cyr, D., Y. Bergeron, S. Gauthier and A.C. Larouche. 2005. Are the old-growth forests of the Clay Belt part of the fire-regulated mosaic. Can. J. For. Res. 35: 65-73.

Cyr, D., S. Gauthier, D.A. Etheridge, G.J. Kayahara and Y. Bergeron. 2010. A simple Bayesian Belief Network for estimating the proportion of old-forest stands in the Clay Belt of Ontario using the provincial forest inventory. Can. J. For. Res. 40: 573-584.

DeBell, D.S., R.O. Curtis, C.A. Harrington and J.C. Tappeiner. 1997. Shaping stand development through silviculture practices. In K.A. Kohm and J.F. Franklin (eds.). Creating forestry for the 21st century: The science of ecosystem management. pp. 141-149. Island Press, Washington, DC. 475 p.

Drescher, M., A.H. Perera, L.J. Buse, K. Ride and S. Vasiliauskas. 2008. Uncertainty in expert knowledge for forest succession: A case study from boreal Ontario. For. Chron. 84: 194-209.

Ecoregions Working Group. 1989. Ecoclimatic regions of Canada, First Approximation. Ecoregions Working Group of the Canada Committee on Ecological Land Classification. Sustainable Development Branch, Canadian Wildlife Service, Conservation and Protection, Environment Canada, Ottawa, Ontario. Ecological Land Classification Series No. 23. 119 p.

Fall, A., M.J. Fortin, D.D. Kneeshaw, S.H. Yamasaki, C. Messier, L. Bouthillier and C. Smyth. 2004. Consequences of various landscapescale ecosystem strategies and fire cycles on age-class structure and harvest in boreal forests. Can. J. For. Res. 34: 310-322.

Fleming, R.A., A.A. Hopkin and J.-N. Candau. 2000. Insect and disease disturbance regimes in Ontario's forests. In A.H. Perera, D.L. Euler and I.D. Thompson (eds.). Ecology of a managed terrestrial landscape: Pattern and processes of forest landscapes in Ontario. pp. 141-162. UBC Press, Vancouver, BC. 336 p.

Franklin, J.F. 1993. Preserving biodiversity: species, ecosystems or landscapes. Ecol. Appl. 3: 202-205.

Galindo-Leal, C. and F.L. Bunnell. 1995. Ecosystem management: Implications and opportunities of a new paradigm. For. Chron. 71: 601-606.

Garet, J., D. Pothier and M. Bouchard. 2009. Predicting the longterm yield trajectory of black spruce stands using time since fire. For. Ecol. Manage. 257: 2189-2197.

Grenier, D.J., Y. Bergeron, D. Kneeshaw and S. Gauthier. 2005. Fire frequency for the transitional mixedwood forest of Timiskaming, Quebec, Canada. Can. J. For. Res. 35: 656-666.

Harper, K.A., Y. Bergeron, P. Drapeau, S. Gauthier and L. De Granpré. 2005. Structural development following fire in black spruce boreal forest. For. Ecol. Manage. 206: 293-306.

Harper, K.A., Y. Bergeron, S. Gauthier and P. Drapeau. 2002. Postfire development of canopy structure and composition in black spruce forests of Abitibi, Québec: A landscape scale study. Silva Fennica 36: 249-263.

Harper, K., C. Boudreault, L. DeGrandpré, P. Drapeau, S. Gauthier and Y. Bergeron. 2003. Structure, composition, and diversity of oldgrowth black spruce boreal forest of the Clay Belt region in Quebec and Ontario. Environ. Rev. 11: S879-S98.

Harris, L.D. 1984. The fragmented forest: Island biogeography theory and the preservation of biotic diversity. University of Chicago Press, Chicago, ILL. 211 p.

Harvey, B.D., A. Leduc, S. Gauthier and Y. Bergeron. 2002. Standlandscape integration in natural disturbance-based management of the southern boreal forest. For. Ecol. Manage. 155: 369-385.

Ilisson, T. and H.Y.H Chen. 2009. Response of six boreal tree species to stand-replacing fire and clearcutting. Ecosystems 12: 820-829.

Keeton, W.S. 2006. Managing for late-succession/old-growth characteristics in northern hardwood-conifer forests. For. Ecol. Manage. 235: 129-142.
Kelty, M.J., D.B. Kittredge, Jr., T. Kyker-Snowman and A.D Leighton. 2003. The conversion of even-aged stands to unevenaged structure in southern New England. North. Jour. Appl. For. 20: 109-116.

Lefort, P. 2003. Ecology and management of claybelt forests: A knowledge synthesis. Report contract with the Lake Abitibi Model Forest. ISBN: 1-896916-28-7.

Lefort, P., S. Gauthier and Y. Bergeron. 2003. The influence of fire weather and land use on the fire activity of the Lake Abitibi Area, Eastern Canada. For. Sci. 49: 509-521.

Lefort, P., B. Harvey, J. Parton and G.K.M. Smith. 2002. Synthesizing knowledge of the Claybelt to promote sustainable forest management. For. Chron. 78: 665-671.

Martell, D.L. and H. Sun. 2008. The impact of fire suppression, vegetation, and weather on the area burned by lightning-caused forest fires in Ontario. Can. J. For. Res. 38: 1547-1563.

Moore, T. and G. Tink. 2008. Technical considerations in the design of core habitat patches in forest management: A case study using the Patchworks spatial model. For. Chron. 84: 731-740.

Nyland, R.D. 2003. Even- to uneven-aged: the challenges of conversion. For. Ecol. Manage. 172: 291-300.

[OMNR] Ontario Ministry of Natural Resources. 2005. Forest Management Plan for the Gordon Cosens Forest Management Unit, 2005-2010. Plan filed with the OMNR, NE Regional Office, South Porcupine, $\mathrm{ON}$.

2009. Forest management planning manual for Ontario's Crown forests. Queen's Printer for Ontario, Toronto, ON. 447 p.

Paré, D. and Y. Bergeron. 1995. Above-ground biomass accumulation along a 230-year chronosequence in the southern portion of the Canadian boreal forest. Jour. Ecol. 83: 1001-1007.

Parton, J., S. Vasiliauskas, G. Lucking and W.R. Watt. 2006. Standard forest units for northeastern Ontario boreal forests. Ont. Min. Nat. Res., NE Sci. Info., South Porcupine, ON. NESI Tech. Note TN-021. 23 p.

Penner, M. 2008. Yield prediction for mixed species stands in boreal Ontario. For. Chron. 84: 46-52.

Penner, M., M. Woods, J. Parton and A. Stinson. 2008. Validation of empirical yield curves for natural-origin stands in boreal Ontario. For. Chron. 84: 704-717.

Plonski, W.L. 1981. Normal yield tables (metric) for major forest species of Ontario. Silvicultural Series Bulletin no.2, Ontario Ministry of Natural Resources, Toronto, ON. 40 p.

Rouillard, D. and T. Moore. 2008. Patching together the future of forest modeling: Implementing a spatial model in the 2009 Romeo Malette Forest Management Plan. For. Chron. 84: 718-730.

Seymour, R.S. and M.L. Hunter, Jr. 1999. Principles of ecological forestry. In: M.L. Hunter, Jr. (ed.). Maintaining biodiversity in forest ecosystems. Cambridge University Press, New York. 698 p.

Sharma, M., J. Parton, M. Woods, P. Newton, M. Penner, J. Wang, A. Stinson and F.W. Bell. 2008. Ontario's forest growth and yield modelling program: Advances resulting from the Forestry Research Partnership. For. Chron. 84: 694-703.

Taylor, A.R. and H.Y.H. Chen. 2011. Multiple succession pathways of boreal forest stands in central Canada. Ecography 34: 208-219.

The Nature Conservancy. 1982. The natural heritage program operations manual. The Nature Conservancy, Arlington, VA.

Vasiliauskas, S., H.Y.H. Chen, J. Parton, P. Henry, G. Lucking, M. Brienesse, S. Osawa and R. Arnup. 2004. Succession pathways proposed for SFMM rules for northeast regional standard forest units. Ont. Min. Nat. Res., NE Sci. Info., South Porcupine, ON. NESI Tech. Note TN-020. 12 p.

Woods, M., D. Pitt, M. Penner, K. Lim, D. Nesbitt, D. Etheridge and P. Treitz. 2011. Operational implementation of a LiDAR inventory in Boreal Ontario. For. Chron. 87: 512-528.

Yemshanov, A. and A.J. Perera. 2001. Modelling boreal forest succession at broad scales: A North American bibliography. Ontario Forest Research Institute, Ontario Ministry of Natural Resources, Sault Ste. Marie, ON. For. Res. Inf. Pap. No. 146. 46 p. 